\title{
Phosphate transporter genes: genome-wide identification and characterization in Camelina sativa
}

\author{
Soosan Hasanzadeh ${ }^{1}$, Sahar Faraji ${ }^{2}$, Abdullah ${ }^{3}$, Parviz Heidari ${ }^{1, *}$ \\ 1 Faculty of Agriculture, Shahrood University of Technology, 3619995161 Shahrood, Iran \\ 2 Faculty of Crop Sciences, Sari Agricultural Sciences and Natural Resources University (SANRU), Sari 4818166996, Iran \\ 3 Department of Biochemistry, Faculty of Biological Sciences, Quaid-i-Azam University, 45320 Islamabad, Pakistan \\ * Correspondence: Parviz Heidari, Email: heidarip@ shahroodut.ac.ir
}

\begin{abstract}
Phosphorus is known as a key element associated with growth, energy, and cell signaling. In plants, phosphate transporters (PHTs) are responsible for moving and distributing phosphorus in cells and organs. PHT genes have been genome-wide identified and characterized in various plant species, however, these genes have not been widely identified based on available genomic data in Camellia sativa, which is an important oil seed plant. In the present study, we found $66 P H T$ genes involved in phosphate transporter/translocate in $C$. sativa. The recognized genes belonged to PHTs1, PHTs2, PHTs4, PHOs1, PHO1 homologs, glycerol-3-PHTs, sodium dependent PHTs, inorganic PHTs, xylulose 5-PHTs, glucose-6-phosphate translocators, and phosphoenolpyruvate translocators. Our finding revealed that PHT proteins are divers based on their physicochemical properties such as Isoelectric point (pI), molecular weight, GRAVY value, and exon-intron number(s). Besides, the expression profile of $P H T$ genes in $C$. sativa based on RNA-seq data indicate that PHTs are involved in response to abiotic stresses such as cold, drought, salt, and cadmium. The tissue specific expression high expression of $P H O 1$ genes in root tissues of C. sativa. In additions, four PHTs, including a PHT4;5 gene, a sodium dependent PHT gene, and two PHO1 homolog 3 genes were found with an upregulation in response to aforementioned studied stresses. In the current study, we found that PHO1 proteins and their homologs have high potential to post-translation modifications such as $\mathrm{N}$-glycosylation and phosphorylation. Besides, different cis-acting elements associated with response to stress and phytohormone were found in the promoter region of PHT genes. Overall, our results show that PHT genes play various functions in C. Sativa and regulate Camellia responses to external and intracellular stimuli. The results can be used in future studies related to the functional genomics of $C$. sativa.
\end{abstract}

Keywords: Genome study, Ion transporters, Gene expression, Post-translation modifications, Abiotic stresses.

\section{Introduction}

Phosphorus (P) is one of the main macronutrients, which form many fundamental structures and regulate various processes of the plant cells. It serves the cell as a constitutive part of DNA, RNA, and membrane phospholipids, as a key element in energy metabolism and transfer, and as a component in signal transduction, photosynthesis, the metabolism of sugars, and respiration (Raghothama, 2000). Plants uptake only the inorganic phosphorus forms $\left(\mathrm{Pi}: \mathrm{H}_{2} \mathrm{PO}_{4}^{-}\right.$and $\mathrm{HPO}_{4}{ }^{2-}$ ). The slow rate of diffusion and high interaction of $\mathrm{P}$ with other elements (like $\mathrm{Al}, \mathrm{Fe}$, and $\mathrm{Ca}$ ) in the soil make it least available macronutrient in the rhizosphere (Smith et al., 2003). The concentration of available $\mathrm{P}$ in soil barely gets to $10 \mu \mathrm{M}$, while concentration of Pi in plant cells is 
generally more than $10 \mathrm{mM}$ (Tran et al., 2010). Therefore one of the most specialized plant strategies to acquire Pi is phosphate transporters (PHTs) (Smith, 2002). Two systems for Pi transporters in plants have been identified: The high-affinity phosphate transporters function at $\mu \mathrm{M}$ range of $\mathrm{Pi}$ concentration which is the usual $\mathrm{Pi}$ concentration in cultivated soils (Poirier and Bucher, 2002). On the other hand, the low-affinity phosphate transporters operate at mM range of Pi concentration (Karthikeyan et al., 2002). Plants employ multiple PHT families including PHT1, PHT2, PHT3, PHT4, PHT5, and PHO1 (Yang et al., 2020; Zhang et al., 2016). PHT1 is a $\mathrm{Pi}: \mathrm{H}^{+}$symporter with a high affinity for $\mathrm{Pi}$, which is localized in the plasma membrane and belongs to the major facilitator superfamily (MFS) (Nussaume et al., 2011). AtPHT1 was the first PHTs identified in higher plants (Muchhal et al., 1996). In Arabidopsis thaliana, the PHTl family consists of nine homologs which eight of them are expressed in root tissues (Młodzińska and Zboińska, 2016). Among PHT1 homologs, AtPHT1;1 and AtPHT1;4 play significant roles in Pi uptake under both sufficient and deficient pi concentrations (Shin et al., 2004). AtPHT1;8 and AtPHT1;9 participate in Pi translocation from root to shoot and both function in phosphate uptake under Pi deficiency (Remy et al., 2012). In Oryza sativa, 13 homologs for OsPHTl have been identified which all of them are expressed in rice roots (Jia et al., 2011). A recent study by upregulation of seven PHTI subfamily genes in rice showed that phosphate uptake from the soil under phosphorus deficiency considerably relies on PHT1 (Gho and Jung, 2019). PHT2 is a low-affinity Pi: $\mathrm{H}^{+}$symporter present in the chloroplast envelope (Daram et al., 1999). The activity of PHT2 impacts on Pi allocation inside the plant; it also moderates the plant's responses to $\mathrm{Pi}$ starvation through translocating of $\mathrm{Pi}$ inside the leaves and induction and expression of $\mathrm{Pi}$ starvation response genes (Versaw and Harrison, 2002). PHT3 or Mitochondrial Phosphate Transporter (MPT) family is a high-affinity PHT, which is localized to the inner mitochondrial membrane and Its function was reported to be Pi: $\mathrm{H}^{+}$symporter and $\mathrm{Pi}: \mathrm{OH}^{-}$antiporter (Lee and Yoon, 2018). It is PHT3 responsibility to provide the required phosphate for ATP synthesis by transporting Pi from the cytosol into the mitochondrial matrix (Yu et al., 2018). Three homologs for Arabidopsis PHT3 (AtPHT3;1-3) and six for rice PHT3 genes have been identified (Huang et al., 2020). The expression of PHT4 genes takes place both in roots and leaves. PHT4;1 is a thylakoid membrane PHT, which appears to be involved in defense against pathogens (Guo et al., 2008), while PHT4;2 transports Pi within root's heterotrophic plastids and affects starch accumulation as well (Sun et al., 2017). PHT4;4 is an ascorbate transporter located in the chloroplast inner envelope membrane, which is associated with protection from high light stress (Miyaji et al., 2015). PHT4;6 is localized to the Golgi apparatus and cooperates with salt tolerance (Cubero et al., 2009). Oryza sativa also has six PHT4 genes, which are very well described in a previous study (Ruili et al., 2020). PHT5 family acts as a vacuolar PHT and consists of three members in Arabidopsis (Liu et al., 2016). Regarding PHO1, using a map-based positional cloning strategy led to the identification of this gene family in Arabidopsis (Hamburger et al., 2002). The Arabidopsis genome contains 11 members of the $\mathrm{PHO1}$ gene family, which are localized to the endomembrane (majorly Golgi) of root pericyclic cells (Gu et al., 2016; Liu et al., 2012). The expression pattern of all PHOI homologs proposes that PHO1, in addition to transporting Pi to the vascular cylinders in various tissue, also has a probable role in phosphate acquiring into cells, like pollen or root epidermal/cortical cells (Wang et al., 2004). Under Pi deficiency, PHOI also plays a part in the long distance (root-to-shoot) signal transduction cascade (Młodzińska and Zboińska, 2016).

Camelina sativa is an oilseed member of Brassicaceae, which has gained great attention due to its high potential for biofuel production (Ahmadizadeh et al., 2020b; Murphy, 2016). Also, C. sativa is resistant to doughtiness, salinity and coldness and many pathogens (Brock et al., 2018). A study on C. sativa seed yield 
bioRxiv preprint doi: https://doi.org/10.1101/2021.02.28.433256; this version posted March 1, 2021. The copyright holder for this preprint (which was not certified by peer review) is the author/funder, who has granted bioRxiv a license to display the preprint in perpetuity. It is made available under aCC-BY-NC-ND 4.0 International license.

response to various fertilizers showed that maximum predicted seed yield was obtained without using Pi fertilizer (Solis et al., 2013). To reduce reliance on Pi fertilizers and ensuring sustainable agriculture, it is required to identify and characterize PHTs especially in low input crops such as $C$. sativa, to be able to develop Pi-efficient crops. Genomic analyses of PHT families have been conducted on various plants, including Arabidopsis, rice (Liu et al., 2011), poplar (Zhang et al., 2016), Apple (Sun et al., 2017), sorghum (Wang et al., 2019), and rapeseed (Yang et al., 2020). However, none of the report available for C. sativa. In this study, we conduct a comprehensive genome-wide analysis to identify and characterize PHT gene families in C. sativa and provide functional dissection of CsPHTs.

\section{Materials and methods}

\section{Recognition of phosphate transporter family members in Camelina sativa}

PHT proteins of the model plant Arabidopsis were used as queries in BLASTP tool search (E-value $<1 \mathrm{e}-$ 5) from the Ensembl Plants database (Bolser et al., 2017) to identify and retrieve genes encoded phosphate transporter (PHT) proteins in C. sativa. The identified PHTs were analyzed using Pfam (Finn et al., 2010) and Bach CDD-search of NCBI database (Marchler-Bauer et al., 2015) to check the presence of the common conserved domains and avoid truncated protein. We also retrieved sequences of genomic DNA, cDNA, and promoter regions. Furthermore, the ProtParam tool of ExPASy (Gasteiger et al., 2005) was applied to predict the isoelectric points ( $p I)$, molecular weights (MW), and the grand average of hydropathy (GRAVY).

\section{Evolutionary analysis}

For the evolutionary study, the protein sequences of phosphate transporter genes in $C$. sativa along with their orthologues in model plants, rice and Arabidopsis, were aligned by multiple alignment using the clustalW method. The phylogenetic relationship of the phosphate transporter genes was created using the unrooted neighbor-joining method of MEGA X (Kumar et al., 2018) with 1000 bootstrap replicates and finally, the created phylogeny tree was improved using an interactive tree of life (Letunic and Bork, 2019).

\section{Gene expression}

To study the expression profile of phosphate transporter genes, the available RNA-seq data related to $C$. sativa was screened to determine the expression levels of the phosphate transporter family members. In the present study, the RNA-seq data in leaf, flower, stem, and root of C. sativa were selected from the NCBI database with available accessions SRR935362, SRR935369, SRR935365, and SRR935368, respectively. Besides, RNAseq data related to abiotic stresses, including drought stress (SRR935380), $\mathrm{NaCl}$ stress (SRR935382), cold stress (SRR935372), cadmium stress (SRR935383), and normal condition (SRR935385), were evaluated to state the expression pattern of phosphate transporter genes in C. sativa. The transcript levels of phosphate transporter genes were calculated using FPKM (fragments per kilobase of exon model per million mapped reads). Finally, heatmaps were created using $\log 2$ transformed by TBtools software (Chen et al., 2020).

\section{Promoter region analyses and prediction of post-translational modifications of PHT proteins}

The promoter region (1500 bps upstream of the start codon) of phosphate transporter genes in C. sativa was screened to find key cis-regulatory elements related to response to stresses and hormones using the PlantCare 
bioRxiv preprint doi: https://doi.org/10.1101/2021.02.28.433256; this version posted March 1 , 2021. The copyright holder for this preprint (which was not certified by peer review) is the author/funder, who has granted bioRxiv a license to display the preprint in perpetuity. It is made available under aCC-BY-NC-ND 4.0 International license.

database (Lescot et al., 2002). The phosphorylation and N-glycosylation modification as important types of posttranslational modifications were predicted in phosphate transporter proteins in $C$. sativa. The potential phosphorylation site was estimated using NetPhos 3.1 server (Blom et al., 2004) with potential value $>0.5$ and NetNGlyc 1.0 server (Gupta and Brunak, 2002) was used to predict the N-glycosylation sites into the amino acid sequence of phosphate transporter proteins.

\section{Results}

In the genome of $C$. sativa, we identified sixty six non redundant $P H T$ genes, including eight $P H T 1$ genes, three PHT2 genes, ten PHT4 genes, three PHO1 genes, nineteen PHO1 homolog genes, eight glycerol-3PHT genes, three sodium dependent PHT genes, four probable inorganic PHT genes, three xylulose 5-PHT genes, three glucose-6-phosphate translocator genes, and two phosphoenolpyruvate translocator genes (Table 1). The recognized PHT proteins showed a high diversity based on physicochemical properties such as pI, molecular weight, GRAVY value, exon number, and protein length. Exon number of studied PHTs varied from 1 to 20 and protein length ranged from 209 to 1230 aa. Furthermore, pI showed a variation between 5.11 and 10.11 in phosphate transporter/translocate proteins of $C$. sativa. Besides, the GRAVY value revealed that all PHO homolog proteins are hydrophilic proteins. The studied PHT genes were distributed on 20 chromosomes of $C$. sativa (Fig. 1). Most phosphate transporter genes were located in chromosome 6 (eight genes) and chromosome 9 (nine genes). Chromosomes 1, 15, and 19 each had a PHO gene, and chromosomes 2 and 12 had a glycerol-3-PHT gene. Besides, the location (start and end position) of each phosphate transporter/translocate gene on the Camelina chromosome is also mentioned in Table 1. Our results revealed the unequal distribution of phosphate transporter/translocate genes within $C$. sativa genome.

Table 1- Properties of recognized phosphate transporter genes into C. sativa genome

\begin{tabular}{|c|c|c|c|c|c|c|c|c|}
\hline Gene ID & Description & Chr. location & $\begin{array}{l}\text { CDS } \\
\text { (bp) }\end{array}$ & Exon & $\begin{array}{l}\text { Peptide } \\
\text { (aa) }\end{array}$ & $\begin{array}{c}\text { MW } \\
(\mathbf{k D a})\end{array}$ & pI & GRAVY \\
\hline Csa05g014350 & PHT1 & 5:5014921-5018711 & 2223 & 2 & 534 & 58.73 & 8.35 & 0.294 \\
\hline $\mathrm{Csa04g052890}$ & PHT1 & $4: 25092914-25096711$ & 1381 & 2 & 392 & 42.75 & 7.00 & 0.455 \\
\hline Csa06g042880 & PHT1 & $6: 21171097-21174709$ & 2275 & 2 & 534 & 58.69 & 8.35 & 0.299 \\
\hline Csa09g081170 & Putative PHT & 9:30797478-30800557 & 1593 & 2 & 530 & 58.51 & 8.54 & 0.466 \\
\hline Csa07g047990 & Putative PHT & $7: 24682311-24685313$ & 1590 & 2 & 529 & 58.36 & 8.93 & 0.454 \\
\hline Csa16g040570 & Putative PHT & $16: 20731839-20736565$ & 3305 & 2 & 530 & 58.47 & 8.54 & 0.478 \\
\hline Csa03g024720 & PHT1;8 & 3:9470369-9472993 & 1611 & 2 & 536 & 59.10 & 6.52 & 0.381 \\
\hline Csa14g026060 & PHT1;8 & 14:10079381-10081989 & 1611 & 2 & 536 & 59.08 & 6.46 & 0.385 \\
\hline Csa06g006270 & PHT2;1 & $6: 3480684-3482786$ & 1880 & 3 & 587 & 61.22 & 9.34 & 0.554 \\
\hline Csa09g010040 & PHT2;1 & $9: 4351633-4354047$ & 2201 & 3 & 587 & 61.27 & 9.34 & 0.558 \\
\hline $\mathrm{Csa04g012130}$ & PHT2;1 & 4:5383653-5386072 & 2192 & 3 & 587 & 61.32 & 9.39 & 0.534 \\
\hline Csa06g040800 & PHT4;2 & $6: 20643394-20647032$ & 1892 & 8 & 509 & 55.59 & 9.68 & 0.515 \\
\hline Csa05g015490 & PHT4;2 & $5: 5626753-5628888$ & 1486 & 7 & 393 & 42.82 & 8.94 & 0.703 \\
\hline $\mathrm{Csa04g051740}$ & PHT4;2 & $4: 24495983-24499701$ & 1948 & 8 & 509 & 54.97 & 9.74 & 0.547 \\
\hline Csa13g023330 & PHT4;5 & $13: 9052618-9057824$ & 1482 & 16 & 209 & 22.98 & 8.46 & 0.001 \\
\hline Csa2Og032330 & PHT4;5 & $20: 10882393-10888480$ & 1503 & 16 & 500 & 54.28 & 5.11 & 0.349 \\
\hline Csa08g014220 & PHT4;5 & $8: 5926491-5931307$ & 1882 & 15 & 525 & 57.55 & 6.43 & 0.252 \\
\hline Csa09g045340 & PHT $4 ; 3$ & $9: 16771385-16774489$ & 2138 & 9 & 533 & 58.18 & 9.66 & 0.464 \\
\hline Csa06g020780 & PHT4;3 & $6: 11456825-11460071$ & 2112 & 9 & 655 & 71.02 & 9.68 & 0.468 \\
\hline Csal1g070280 & PHT4 & $11: 33280938-33283592$ & 2041 & 2 & 432 & 47.08 & 9.44 & 0.678 \\
\hline Csa20g071480 & PHT4 & $20: 24416985-24419803$ & 2110 & 2 & 432 & 47.10 & 9.44 & 0.673 \\
\hline Csa09g096350 & $\begin{array}{c}\text { Glucose-6- } \\
\text { phosphate translocator2 }\end{array}$ & $9: 36509054-36511464$ & 1661 & 5 & 388 & 42.71 & 9.70 & 0.396 \\
\hline Csa07g063090 & $\begin{array}{l}\text { Glucose-6- } \\
\text { phosphate translocator2 }\end{array}$ & $7: 31985709-31987975$ & 1586 & 5 & 389 & 42.81 & 9.66 & 0.387 \\
\hline Csa16g053570 & $\begin{array}{l}\text { Glucose-6- } \\
\text { phosphate translocator2 }\end{array}$ & $16: 27479855-27482074$ & 1491 & 5 & 403 & 44.50 & 9.61 & 0.347 \\
\hline
\end{tabular}


bioRxiv preprint doi: https://doi.org/10.1101/2021.02.28.433256; this version posted March $1,2021$. The copyright holder for this preprint (which was not certified by peer review) is the author/funder, who has granted bioRxiv a license to display the preprint in perpetuity. It is made available under aCC-BY-NC-ND 4.0 International license.

\begin{tabular}{|c|c|c|c|c|c|c|c|c|}
\hline Csa13g020410 & Xylulose 5- PHT & $13: 7578890-7580469$ & 1580 & 1 & 414 & 45.43 & 9.74 & 0.335 \\
\hline Csa20g025800 & Xylulose 5- PHT & $20: 8621980-8623242$ & 1263 & 1 & 420 & 46.16 & 9.74 & 0.285 \\
\hline Csa08g009840 & Xylulose 5- PHT & $8: 4008763-4010025$ & 1263 & 1 & 420 & 46.17 & 9.78 & 0.309 \\
\hline Csa09g064460 & $\begin{array}{c}\text { Probable inorganic PHT1- } \\
7\end{array}$ & $9: 24544974-24548295$ & 1608 & 2 & 535 & 58.63 & 9.05 & 0.457 \\
\hline Csa04g040820 & $\begin{array}{c}\text { Probable inorganic PHT1- } \\
7\end{array}$ & 4:19796739-19799556 & 1938 & 2 & 535 & 58.37 & 8.68 & 0.325 \\
\hline Csa06g029160 & $\begin{array}{c}\text { Probable inorganic PHT } \\
1-7\end{array}$ & $6: 16352706-16355582$ & 1981 & 2 & 535 & 58.42 & 8.68 & 0.325 \\
\hline Csal8g010490 & $\begin{array}{c}\text { Probable } \\
\text { inorganic PHT1-6 }\end{array}$ & 18:5437712-5444775 & 4707 & 6 & 998 & 109.04 & 9.20 & 0.455 \\
\hline Csa09g047740 & Glycerol-3- PHT1 & 9:17201598-17204706 & 2225 & 3 & 526 & 56.45 & 6.32 & 0.411 \\
\hline Csa06g021070 & Glycerol-3- PHT1 & $6: 11705560-11708615$ & 2031 & 3 & 526 & 56.44 & 6.32 & 0.424 \\
\hline Csa11g019360 & Glycerol-3- PHT2 & $11: 8685846-8687786$ & 1857 & 2 & 501 & 54.33 & 6.66 & 0.582 \\
\hline Csa10g017760 & Glycerol-3- PHT2 & 10:7441422-7443017 & 1512 & 2 & 503 & 54.54 & 7.75 & 0.576 \\
\hline Csa12g028010 & Glycerol-3- PHT2 & $12: 8515749-8517468$ & 1636 & 2 & 502 & 54.39 & 6.66 & 0.575 \\
\hline Csal8g026090 & Glycerol-3-PHT1 & 18:13795519-13798239 & 1592 & 5 & 394 & 43.12 & 9.63 & 0.411 \\
\hline Csa02g057110 & Glycerol-3-PHT1 & $2: 21239422-21241966$ & 1386 & 5 & 373 & 40.91 & 9.39 & 0.360 \\
\hline Csallg087830 & Glycerol-3-PHT1 & $11: 42451060-42453885$ & 1807 & 6 & 417 & 45.81 & 9.56 & 0.349 \\
\hline Csa01g028000 & PHO1 & 1:11864045-11869788 & 2343 & 12 & 653 & 74.27 & 9.74 & 0.022 \\
\hline Csa15g044550 & PHO1 & $15: 15190897-15198630$ & 3771 & 20 & 1022 & 117.10 & 9.44 & 0.131 \\
\hline Csa19g033930 & PHO1 & $19: 13491847-13499274$ & 2962 & 14 & 752 & 86.41 & 9.67 & -0.052 \\
\hline Csa07g036190 & PHO1 homolog10 & 7:19504364-19507950 & 2446 & 13 & 759 & 88.96 & 9.03 & -0.229 \\
\hline Csa05g086190 & PHO1 homolog 10 & $5: 31052820-31057418$ & 3343 & 16 & 1055 & 122.84 & 8.00 & -0.343 \\
\hline Csa06g003260 & PHO1 homolog2 & $6: 1774457-1778037$ & 2322 & 12 & 773 & 89.73 & 9.60 & -0.120 \\
\hline Csallg019220 & PHO1 homolog4 & 11:8636753-8639851 & 2238 & 11 & 745 & 87.07 & 9.34 & -0.076 \\
\hline Csa16g030840 & PHO1 homolog10 & $16: 16337025-16340408$ & 2364 & 13 & 787 & 91.35 & 8.85 & -0.217 \\
\hline Csa09g005530 & PHO1 homolog2 & $9: 2199317-2207086$ & 3732 & 20 & 1239 & 143.17 & 9.49 & -0.206 \\
\hline Csa17g063450 & PHO1 homolog8 & $17: 21903188-21907430$ & 3259 & 12 & 750 & 87.40 & 9.15 & -0.097 \\
\hline Csa14g017010 & PHO1 homolog3 & $14: 6684564-6689160$ & 2741 & 12 & 817 & 94.49 & 9.34 & -0.205 \\
\hline Csa03g017780 & PHO1 homolog3 & $3: 6394132-6398776$ & 2894 & 12 & 780 & 89.91 & 9.44 & -0.154 \\
\hline Csa04g018460 & PHO1 homolog9 & 4:9232367-9236955 & 2676 & 17 & 877 & 100.81 & 9.28 & -0.073 \\
\hline Csa06g003190 & PHO1 homolog5 & $6: 1723235-1730512$ & 2926 & 12 & 840 & 96.92 & 8.72 & -0.223 \\
\hline Csa04g008740 & PHO1 homolog5 & 4:2991897-2996176 & 3027 & 12 & 839 & 96.84 & 8.68 & -0.236 \\
\hline Csa09g005520 & PHO1 homolog5 & $9: 2187493-2192729$ & 2980 & 12 & 830 & 95.74 & 8.52 & -0.198 \\
\hline Csa17g019420 & PHO1 homolog3 & $17: 6459607-6470223$ & 2878 & 12 & 816 & 94.16 & 9.31 & -0.180 \\
\hline Csa03g038920 & PHO1 homolog8 & $3: 17838193-17841965$ & 2789 & 12 & 751 & 87.64 & 9.14 & -0.123 \\
\hline Csalog017620 & PHO1 homolog4 & 10:7392473-7399374 & 3730 & 20 & 1171 & 133.75 & 7.52 & -0.460 \\
\hline Csa09g022610 & PHO1 homolog9 & 9:8854639-8859234 & 2412 & 13 & 739 & 85.64 & 9.39 & -0.286 \\
\hline Csa17g034160 & PHO1 homolog7 & $17: 12430216-12433887$ & 2697 & 12 & 751 & 87.70 & 9.26 & -0.051 \\
\hline Csa05g085290 & PHO1 homolog 1 & $5: 30379302-30383384$ & 2700 & 12 & 784 & 90.72 & 9.00 & -0.212 \\
\hline Csa05g034250 & Sodium-dependent PHT1 & $5: 12660817-12663456$ & 1862 & 9 & 509 & 56.38 & 9.08 & 0.282 \\
\hline Csa07g014740 & Sodium-dependent PHT1 & 7:6596929-6599515 & 1772 & 9 & 509 & 56.23 & 9.09 & 0.297 \\
\hline Csa16g015150 & Sodium-dependent PHT1 & $16: 5712825-5714991$ & 1515 & 8 & 504 & 56.15 & 9.31 & 0.284 \\
\hline Csalog038420 & $\begin{array}{l}\text { Phosphoenolpyruvate } \\
\text { translocator } 1\end{array}$ & 10:17811762-17814549 & 1810 & 9 & 449 & 48.73 & 10.08 & 0.520 \\
\hline Csallg044500 & $\begin{array}{l}\text { Phosphoenolpyruvate } \\
\text { translocator } 1\end{array}$ & 11:20839051-20842672 & 1869 & 9 & 408 & 44.21 & 10.11 & 0.449 \\
\hline
\end{tabular}


bioRxiv preprint doi: https://doi.org/10.1101/2021.02 28.433256; this version posted March 1, 2021. The copyright holder for this preprint (which was not certified by peer review) is the author/funder, who has granted bioRxiv a license to display the preprint in perpetuity. It is made available under aCC-BY-NC-ND 4.0 International license.

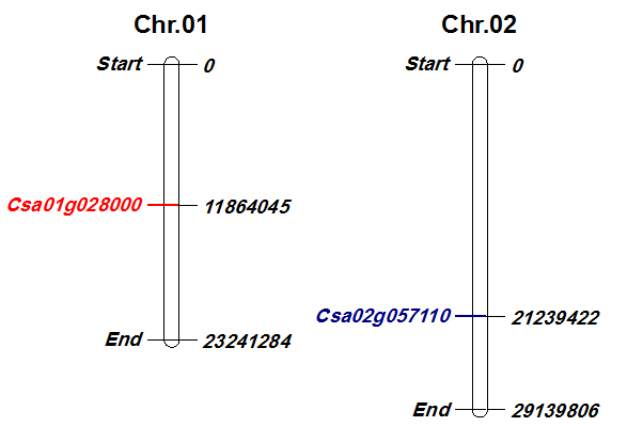

\section{Chr.06}

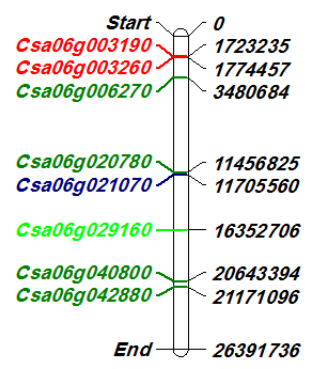

End 26391736
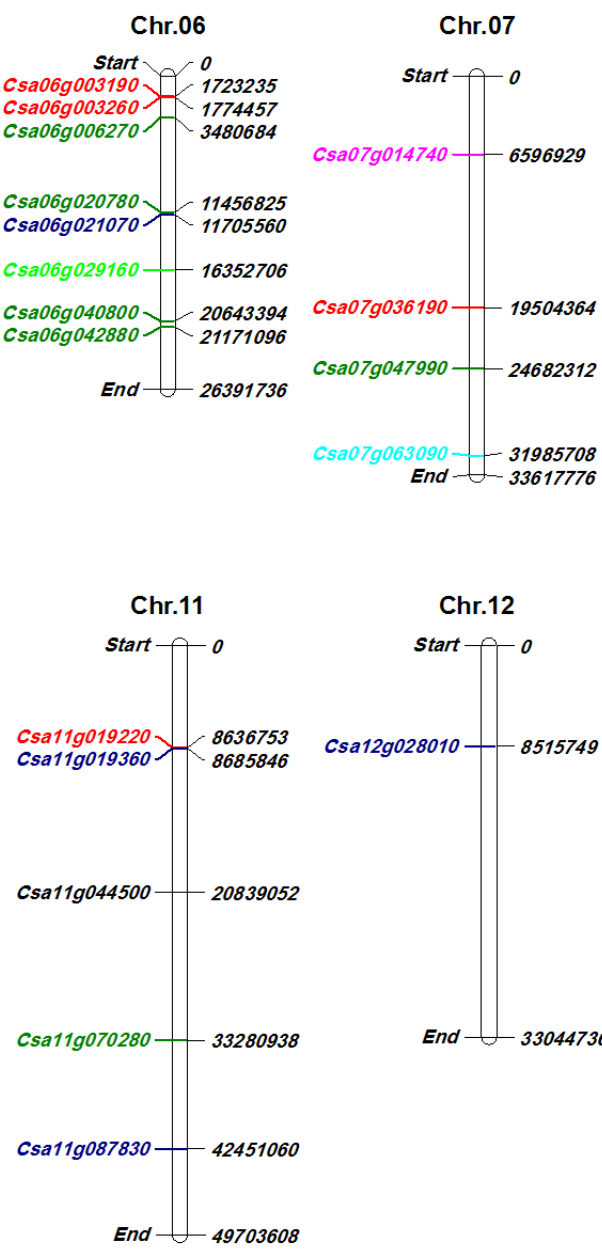

Chr.16

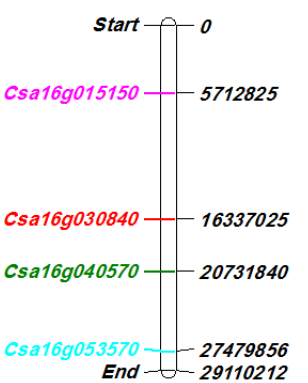

Chr.12

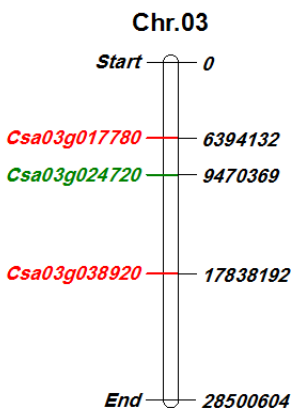

Chr.08

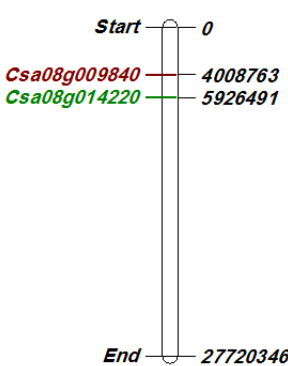

Chr.13

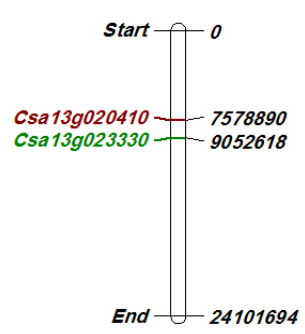

End -33044736
Chr.04

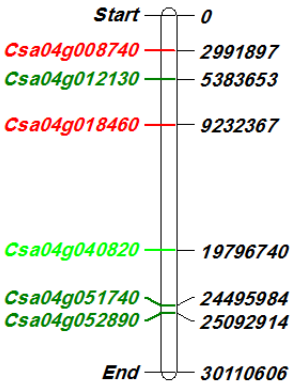

Chr.09

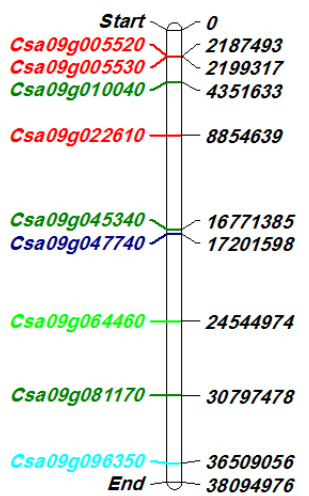

Chr.14

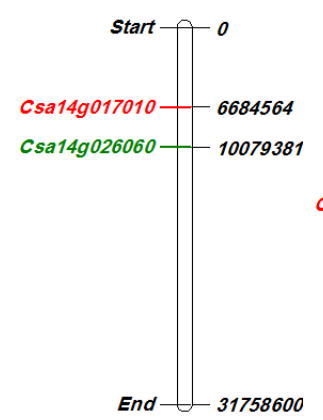

Chr.05

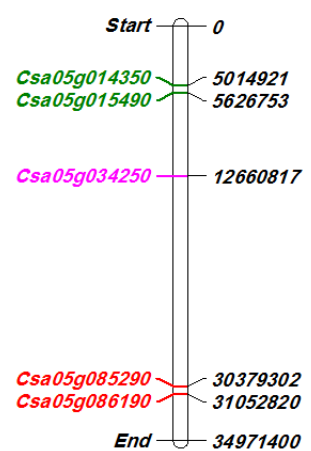

Chr.10

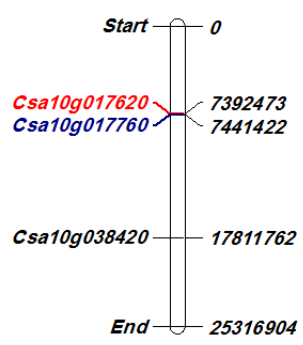

Chr.15

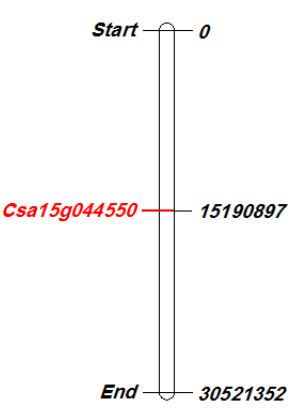

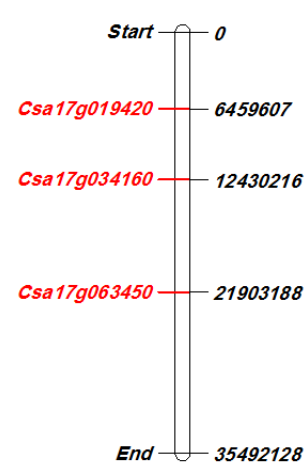

Chr.18

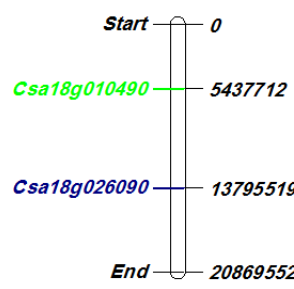

Chr.19

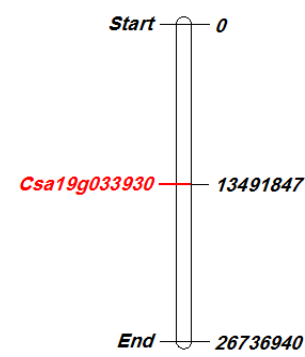

Chr.20

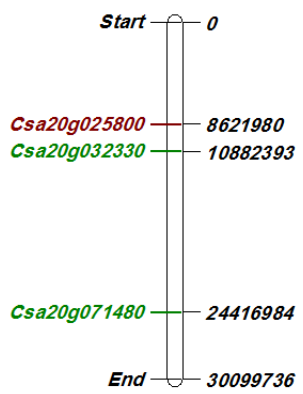


bioRxiv preprint doi: https://doi org/10.1101/2021.02 28.433256. this version posted March 1 2021. The copyright holder for this preprint (which was not certified by peer review) is the author/funder, who has granted bioRxiv a license to display the preprint in perpetuity. It is made available under aCC-BY-NC-ND 4.0 International license.

Fig. 1 Chromosome distribution of PHT genes in C. sativa genome. Different colors used to show the type of phosphate transporter, PHOs1 and PHO1 homologs (red color), PHTs1, PHTs2, and PHTs4 (green color), glycerol-3-PHTs (blue color), sodium dependent PHTs (pink color), probable inorganic PHTs (light green), xylulose 5-PHTs (brown color), glucose-6-phosphate translocators (aqua color), and phosphoenolpyruvate translocators (black color).

\section{Phylogenetic relationships of PHTs}

In the present study, a phylogenetic tree was reconstructed among phosphate transporter/translocate proteins of C. sativa, , Arabidopsis thaliana and Oryza sativa (Fig. 2). The phylogenetic analysis classified PHTs into seven different groups. Two phosphoenolpyruvate translocators, three xylulose 5-PHTs, three glucose-6phosphate translocators as well as three glycerol-3-PHTs of $C$. sativa with their homologs of Arabidopsis and rice were located in the group I. Interestingly, all PHOs of $C$. sativa with their homologous genes were placed in the group II, while group III consisted of rice PHTs. Besides, three PHT2;1 proteins were located in group IV and three PHTs1, three putative PHTs, two PHTs 1;8 with four probable inorganic PHTs were placed in group V. In addition, two glycerol-3-PHTs1 and three glycerol-3-PHTs2 of $C$. sativa with their homologs were located in the group VI. In the group VII, three sodium dependent PHTs showed more relationships with PHT4 proteins. The results revealed that PHTs of $C$. sativa are more similar to their homologs in Arabidopsis and PHTs in rice, as a monocot model plant, have high diversity than studied dicot species. 
bioRxiv preprint doi: https://doi.org/10.1101/2021.02.28.433256; this version posted March 1, 2021. The copyright holder for this preprint (which was not certified by peer review) is the author/funder, who has granted bioRxiv a license to display the preprint in perpetuity. It is made available under aCC-BY-NC-ND 4.0 International license.

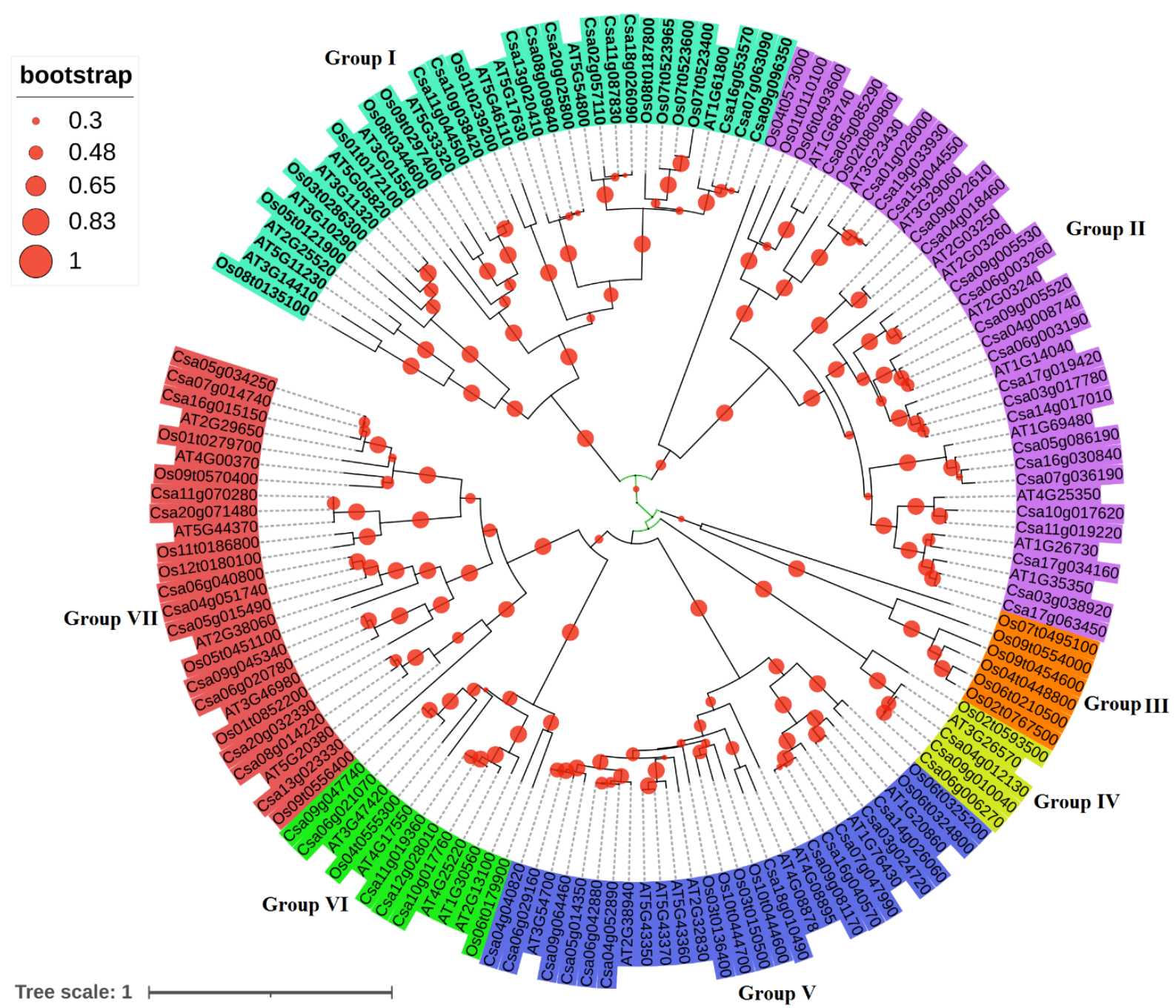

Fig.2 Phylogenetic tree of phosphate transporter proteins in C. sativa with their orthologous in Arabidopsis and rice. Phylogenetic tree was created using NJ method with 1000 bootstrap.

\section{Expression profile of $\mathrm{PHT}$ genes}

The expression level of $P H T$ genes in C. sativa was evaluated in different tissues and in response to abiotic stresses, including cold, $\mathrm{NaCl}$, cadmium, and drought conditions (Fig. 3a, b). Regarding the expression results, PHTs showed diverse expression patterns in various tissues of $C$. sativa (Fig. 3a). Furthermore, our findings revealed that PHTs are more expressed in shoot tissues than root tissues of $C$. sativa (Fig. 4a). Besides, $P H O 1$ genes showed high expression in root tissues than shoot tissues. The expression profile of PHTs under abiotic stresses stated that PHTs are involved in response to drought, cold, salinity, and cadmium stress (Fig. 3b). However, PHTs genes showed differential expression based on the type of stress. For instance, PHTs were more up-regulated in response to cold stress, while they were more down-regulated in response to $\mathrm{NaCl}$ stress (Fig. 4b). In addition, Venn diagrams also showed differential expression patterns of PHTs in response to abiotic stresses (Fig. 4c, d). Regarding the Venn diagrams, four PHTs, including Csa13g023330 (as a PHT4;5 gene), Csa05g034250 (as a sodium dependent PHT gene), and two PHOl homolog3 genes (Csa14g017010 and Csa17g019420) were up regulated in response to all studied abiotic stresses (Fig. 4c). Moreover, a PHO1 homolog5 (Csa09g005520) was identified as a common repressed gene in response to abiotic stresses in C. sativa 
bioRxiv preprint doi: https://doi.org/10.1101/2021.02.28.433256; this version posted March 1, 2021. The copyright holder for this preprint (which was not certified by peer review) is the author/funder, who has granted bioRxiv a license to display the preprint in perpetuity. It is made available under aCC-BY-NC-ND 4.0 International license.

(Fig. 4d). Overall, our findings stated that PHTs are involved in regulating Camelina's responses under environmental stress conditions.
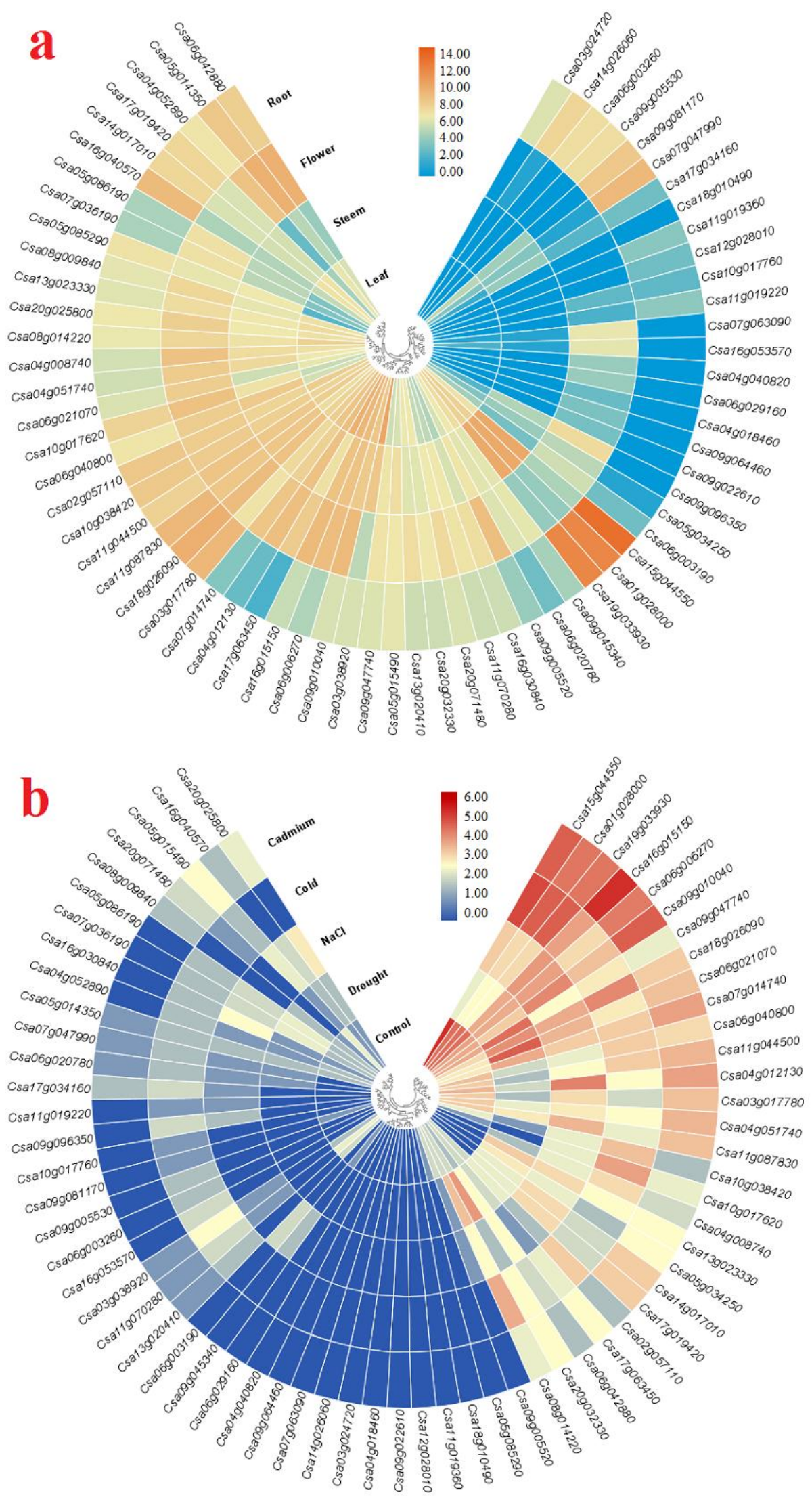
bioRxiv preprint doi: https://doi.org/10.1101/2021.02 28.433256; this version posted March 1, 2021. The copyright holder for this preprint (which was not certified by peer review) is the author/funder, who has granted bioRxiv a license to display the preprint in perpetuity. It is made available under aCC-BY-NC-ND 4.0 International license.

Fig. 3 Expression profile of phosphate transporter genes in C. sativa at different tissues (a), and response to abiotic stress (b).

a

c

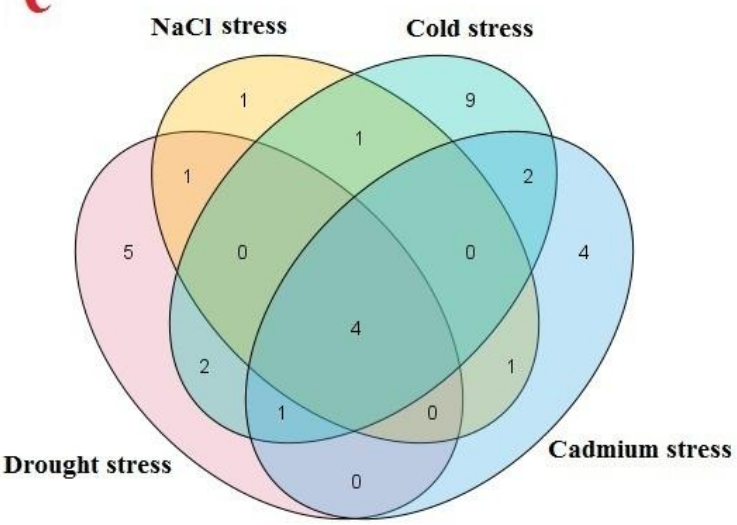

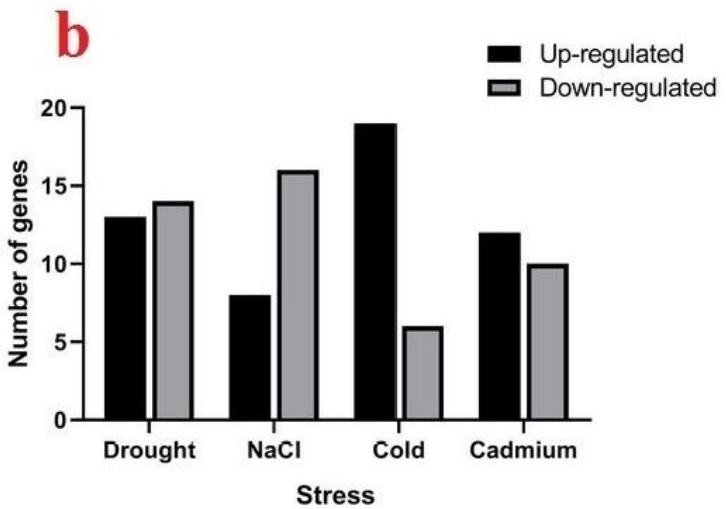

d

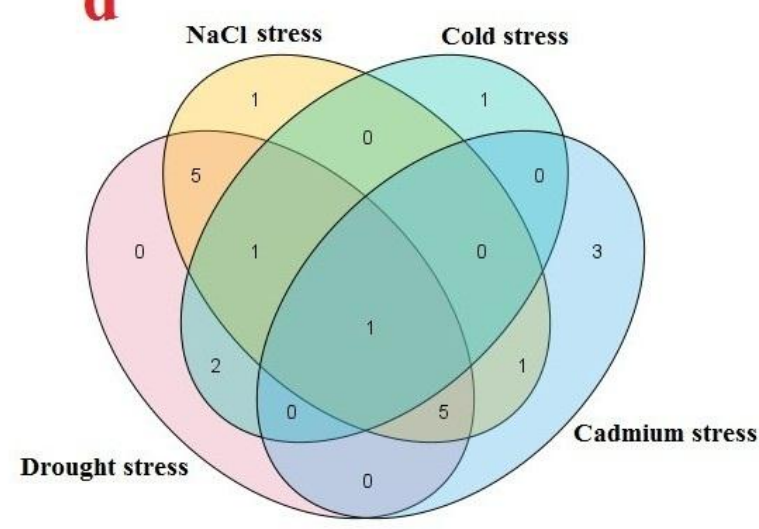

Fig. 4 The number of expressed PHTs in different tissues of C. sativa (a), number of up-regulated and down regulated PHTs in C. sativa genomes in response to abiotic stresses, including drought, $\mathrm{NaCl}$, cold, and cadmium (b), Venn diagram of up-regulated PHT genes (c), and down-regulated PHT genes in response to abiotic stresses (d).

\section{Post- translational modifications}

In the current study, we predicted the potential site of post-translation modifications in terms of phosphorylation and N-glycosylation modifications into PTH proteins of C. sativa (Fig. 5). Regarding the prediction N-glycosylation results, seven PHTs, including two PHT2;1 proteins (Csa06g006270 and Csa09g010040), two PHT4;3 proteins (Csa09g045340 and Csa06g020780), two PHT4 proteins (Csa11g070280 and Csa20g071480), and a PHO1 homolog10 protein (Csa16g030840), were found non site for N-glycosylation (Fig. 5a). Besides, a PHO1 homolog10, Csa03g017780, with seven predicted sites was found as a hyper glycosylation protein and six $\mathrm{N}$-glycosylation sites were predicted in four PHO1 proteins, including PHO1 
bioRxiv preprint doi: https:/doi.org/10.1101/2021.02 28.433256: this version posted March 1, 2021. The copyright holder for this preprint (which was not certified by peer review) is the author/funder, who has granted bioRxiv a license to display the preprint in perpetuity. It is made available under aCC-BY-NC-ND 4.0 International license.

homolog4 (Csa10g017620), PHO1 homolog2 (Csa09g005530), PHO1 homolog7 (Csa17g034160), and PHO1 homolog3 (Csa14g017010). In addition, PHT proteins in C. sativa varied from 20 to 112 sites based on potential phosphorylation modifications (Fig. 5b). A PHT4;5 protein, Csa13g023330, showed a minimum potential phosphorylation site (20 predicted sites), while two PHO1 homolog proteins, including PHO1 homolog4 (Csa10g017620), PHO1 homolog2 (Csa09g005530), were found with high potential sites (112 sites). Overall, the results of prediction of post-translation modifications revealed that PHO1 homolog proteins have more potential for phosphorylation and glycosylation than other PHT proteins in C. sativa.
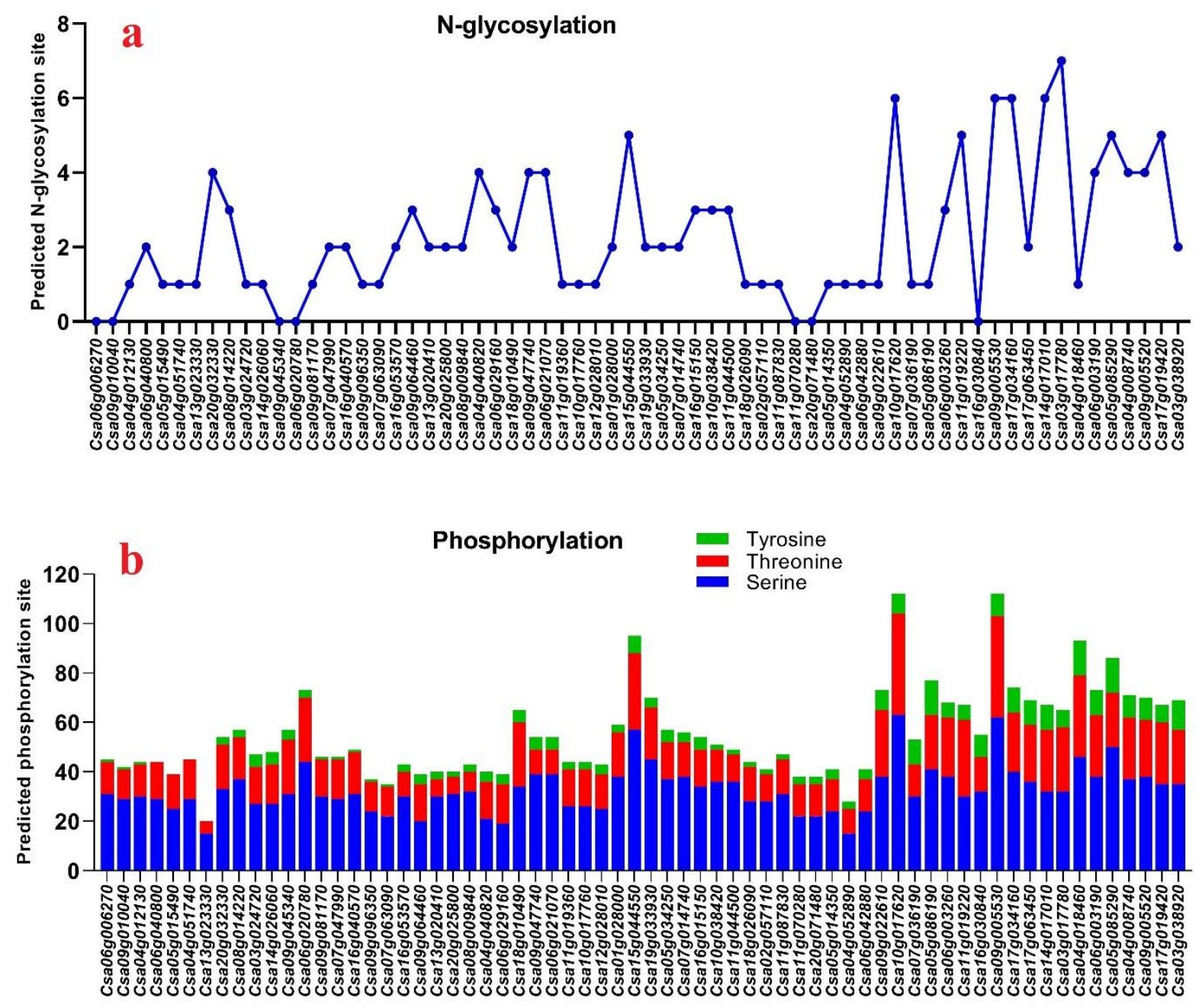

Fig. 5 Number of predicted N-glycosylation (a), and phosphorylation (b) sites of phosphate transporter/translocator proteins in $C$. sativa

\section{Promoter analysis}

In the present study, several key cis-acting elements related to the response of phytohormones and stress conditions were recognized in the promoter region of PHT genes (Fig. 6, 7, and Table 2). The cis-acting elements related to hormones (Table 2), including ABRE, CGTCA, TGA-element, AuxRR-core, TCA-element, P-box, and GARE-motif, were found in the promoter site of PHT genes (Fig. 6). The most promoter regions of the studied 
bioRxiv preprint doi: https://doi.org/10.1101/2021.02 28.433256: this version posted March 1, 2021. The copyright holder for this preprint (which was not certified by peer review) is the author/funder, who has granted bioRxiv a license to display the preprint in perpetuity. It is made available under aCC-BY-NC-ND 4.0 International license.

genes contained ABRE and CGTCA elements related to ABA and MeJA responsiveness, respectively. Besides, promoter site of four genes, including Csa06g006270 (PHT2;1), Csa18g010490 (probable inorganic PHT), Csa15g044550 (PHO1), Csa10g017760 (glycerol-3-PHT), Csa10g038420 (phosphoenolpyruvate translocator), Csa09g096350 (glucose-6-phosphate translocator), and Csa05g086190 (PHO1 homolog10), found with high number of ABRE elements (Fig. 6). Furthermore, cis-acting elements related to the responsiveness of abiotic/biotic stresses were highly found in the promoter region of $P H T$ genes (Fig. 7, Table 2). Two key cisacting elements, MYB and MYC, were highly distributed in the upstream region of $P H T$ genes. Besides, two cisacting elements related to the responsiveness of biotic stress, including WUN-motif and W box, were identified in the promoter site of 29 PHT genes. Furthermore, low-temperature LTR motifs were detected in 19 PHT genes promoter region and drought-responsive MBS element was found in $22 P H T$ genes promoter area. In general, the results revealed that $P H T S$ are involved in various processes related to growth regulation and response to adverse environmental conditions.

Table 2 List of identified cis-acting elements in promoter site of $P H T$ genes in C. sataiva

\begin{tabular}{ccc}
\hline Motif name & Conserved sequence & Function \\
\hline ABRE & ACGTG, CGTACGTGCA & Involved in the abscisic acid responsiveness \\
CGTCA-motif & CGTCA & Involved in the MeJA-responsiveness \\
TCA-element & TCAGAAGAGG, CCATCTTTTT & Involved in salicylic acid responsiveness \\
GARE-motif & TCTGTTG & Gibberellin-responsive element \\
TGA-element & AACGAC & Auxin-responsive element \\
P-box & CCTTTTG & Gibberellin-responsive element \\
AuxRR-cor & GGTCCAT & Involved in auxin responsiveness \\
SARE & TTCGACCATCTT & Involved in salicylic acid responsiveness \\
MYB & CAACCA, CAACAG & Involved in defense and stress responsiveness \\
MYC & CATTTG, CAATTG, CATGTG & Involved in defense and stress responsiveness \\
LTR & CCGAAA & Involved in low-temperature responsiveness \\
MBS & CAACTG & Involved in drought-inducibility \\
TC-rich repeats & GTTTTCTTAC & Involved in defense and stress responsiveness \\
W box & TTGACC & Involved in defense and stress responsiveness \\
WUN-motif & TAATTACTC, AAATTTCCT & Wound-responsive element \\
\hline
\end{tabular}


bioRxiv preprint doi: https://doi.org/10.1101/2021.02.28.433256; this version posted March 1, 2021. The copyright holder for this preprint (which was not certified by peer review) is the author/funder, who has granted bioRxiv a license to display the preprint in perpetuity. It is made available under aCC-BY-NC-ND 4.0 International license.

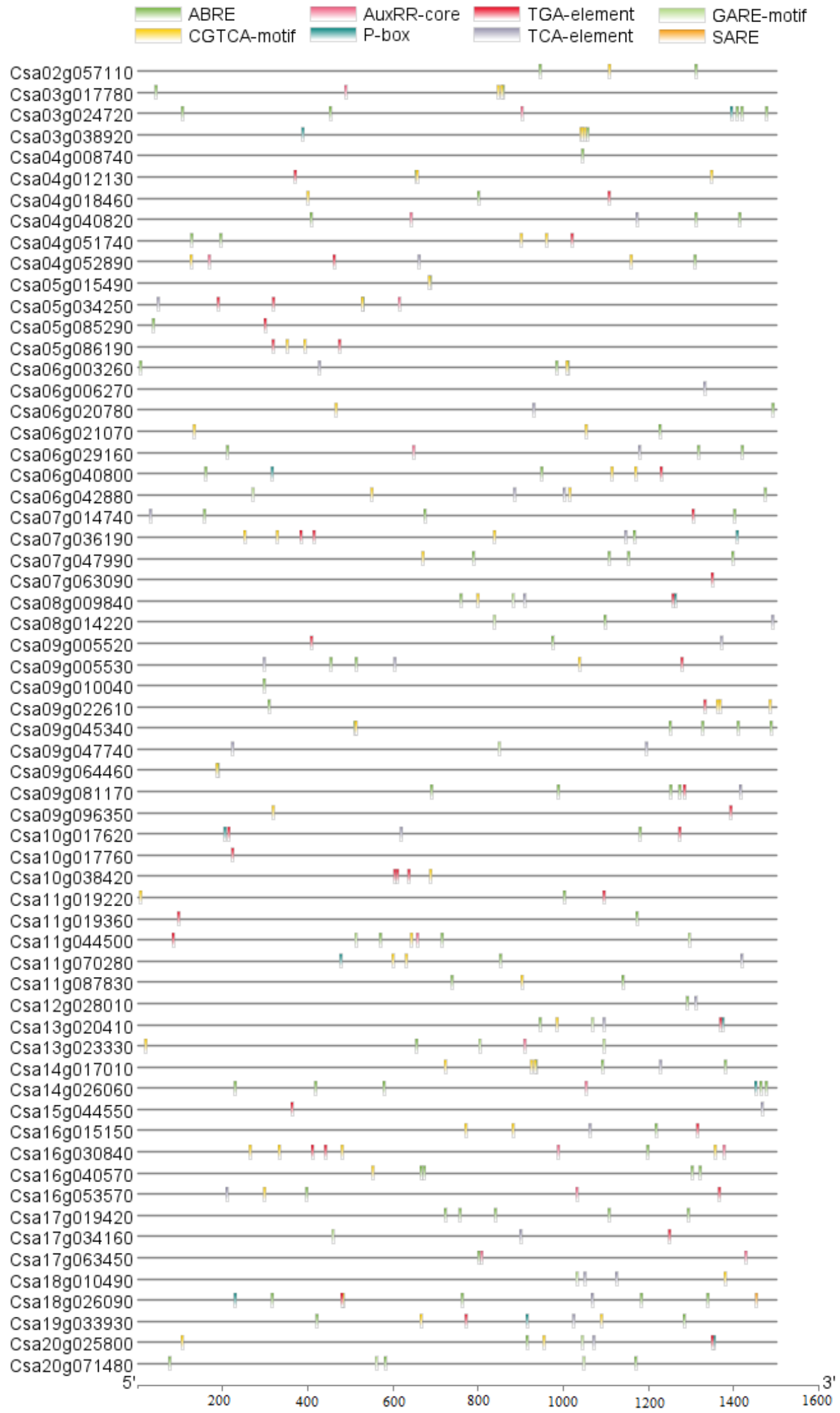

Fig. 6 Distribution of cis-acting elements related to hormone responsive in promoter region of $P H T$ genes in $C$. sativa 
bioRxiv preprint doi: https://doi.org/10.1101/2021.02.28.433256; this version posted March 1, 2021. The copyright holder for this preprint (which was not certified by peer review) is the author/funder, who has granted bioRxiv a license to display the preprint in perpetuity. It is made available under aCC-BY-NC-ND 4.0 International license.

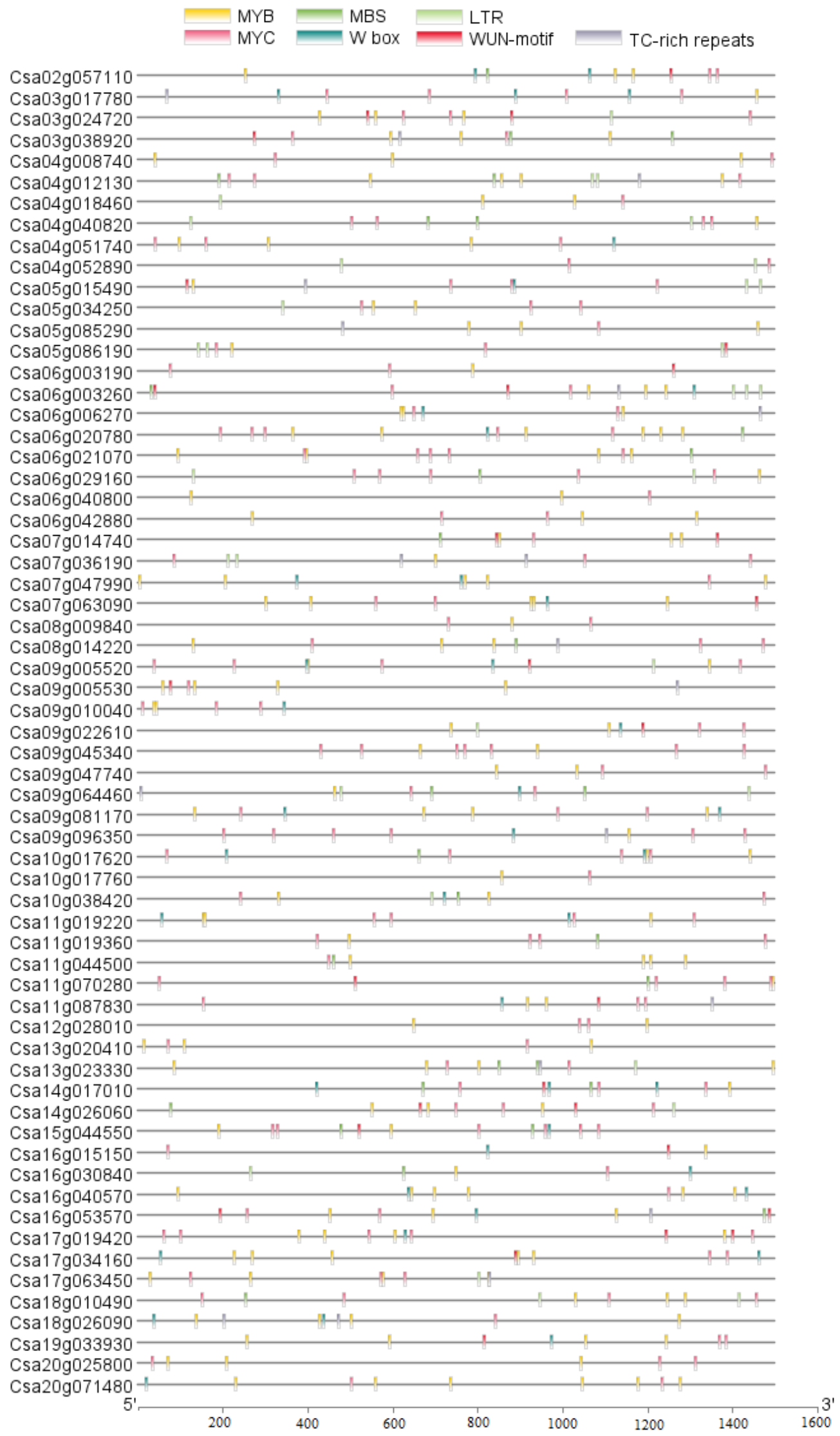

Fig. 7 Distribution of cis-acting elements related to environmental stresses responsive in promoter region of $P H T$ genes in $C$. sativa 
bioRxiv preprint doi: https://doi.org/10.1101/2021.02.28.433256; this version posted March 1, 2021. The copyright holder for this preprint (which was not certified by peer review) is the author/funder, who has granted bioRxiv a license to display the preprint in perpetuity. It is made available under aCC-BY-NC-ND 4.0 International license.

\section{Discussion}

Phosphorus is a key element involved in regulating growth, energy transfer, cell signaling, and increasing plant tolerance to environmental stresses (Raghothama, 2000). In plants, phosphate transporters (PHTs) are responsible for moving and distributing phosphorus in cells and organs (Smith, 2002). Several types of PHT families were recognized and characterized in different plant species, including tomato (Chen et al., 2014), rice (Liu et al., 2011), Sorghum (Wang et al., 2019), Arabidopsis (Guo et al., 2008; Wang et al., 2004), Populus trichocarpa (Zhang et al., 2016), Triticum aestivum (Teng et al., 2017), potato (Liu et al., 2017), and Malus domestica (Sun et al., 2017). However, in plant species such as Camellia sativa, the PHT family genes have not been widely characterized based on available genomic data. In the present study, as the first report, we found 66 PHT genes involved in phosphate transporter/translocate in C. sativa. The recognized genes were belonged to PHT1, PHT2, PHT4, PHO1, PHOl homologs, glycerol-3-PHTs, sodium-dependent PHTs, inorganic PHTs, xylulose 5-PHTs, glucose-6-phosphate translocators, and phosphoenolpyruvate translocators. Regarding the physicochemical properties, the PHT proteins were stated with high diversity in terms of pI, molecular weight, GRAVY value, and exon number, indicating that these transporter genes may be associated with various cellular pathways (Ahmadizadeh et al., 2020a, 2020b). Interestingly, all PHO1 homolog proteins were showed a negative GRAVY value, revealing that the PHO1 homolog proteins are hydrophilic (Heidari et al., 2019; Rezaee et al., 2020). Besides, it was reported that PHT1 proteins are hydrophobic (Nussaume et al., 2011). More exons were observed in $\mathrm{PHOl}$ genes and their homologs that can cause different forms and functional diversity in these genes. Our findings revealed that PHTs in C. sativa with their orthologues in Arabidopsis and rice could be classified into seven different groups that PHTs in rice showed the high distance from studied dicot species. These results illustrate that probably PHT genes of dicot plants are derived from PHT genes of monocot species (Faraji et al., 2020; Heidari et al., 2020a).

The abiotic and biotic stresses reduce plant performance. Previous studies have shown that phosphate transporters are involved in response to biotic and abiotic stresses (Cubero et al., 2009; Hassler et al., 2012). In the present study, the expression analysis of $P H T$ genes in various tissues of $C$. sativa revealed high expression in root tissues of $C$. sativa. These results are an agreement with previous study which also showed the high expression of $\mathrm{PHO1}$ genes in root causes phosphorus to be loaded in xylem (Hamburger et al., 2002; Liu et al., 2012; Młodzińska and Zboińska, 2016). Moreover, other PHTs, including PHTs2, PHTs4, and PHTs3, are more expressed in shoot tissues and involved in the distribution of phosphorus in organelles such as mitochondria, Golgi, and plastids (Gho and Jung, 2019). The RNA-seq analyses of various abiotic stresses showed role pf PHTs genes in drought, cold, salinity, and cadmium stress in $C$. sativa. Interestingly. However, these genes were more up-regulated in response to cold stress. It was stated that deficiency in phosphorus transfer could cause sensitivity to environmental stresses such as salinity (Cubero et al., 2009). There is a hypothesis that PHTs are involved in maintaining ionic balance in the cytoplasm, which probably increases the resistance of plants to stress. Under the stress of the heavy metal such as cadmium, various mechanisms have been proposed that transporters and cellular pumps play an important role in reducing the toxicity and maintaining the ionic balance (Heidari et al., 2020b; Heidari and Panico, 2020). It seems that PHT genes are involved in response to cadmium stress in C. sativa.

Regarding the Venn diagrams, we found that four PHTs, including a PHT4;5 gene, a sodium-dependent PHT gene, and two $\mathrm{PHO1}$ homolog3 genes are up-regulated in response to all studied stresses. Interestingly, two $\mathrm{PHO1}$ 
bioRxiv preprint doi: https://doi.org/10.1101/2021.02.28.433256; this version posted March 1, 2021. The copyright holder for this preprint (which was not certified by peer review) is the author/funder, who has granted bioRxiv a license to display the preprint in perpetuity. It is made available under aCC-BY-NC-ND 4.0 International license.

homolog3 genes with high expression levels also were identified as the hyperglycosylated proteins. Glycosylation modifications as a post-translation modification can affect the stability and dynamics of target proteins Lee et al. (2015). In general, PHOs1 and their homologs were predicted with high potential N-glycosylation and phosphorylation sites. Post-translation modifications such as phosphorylation processes cause significant effects on protein activities and inducing cell signaling (Heidari et al., 2020a; Silva-Sanchez et al., 2015). The high phosphorylation potential of $\mathrm{PHO} 1$ proteins may indicate that these proteins are involved in various cellular processes under signal transduction pathways (Ahmadizadeh et al., 2020a). Regarding the promoter region analysis, various cis-acting elements associated with response to stress conditions and phytohormones were found in the upstream region of $P H T$ genes. The cis-regulatory elements play a critical role in the regulation of gene expression that can be induced by external stimuli or induced signaling pathways in response to biotic and abiotic stresses (Ahmadizadeh and Heidari, 2014; Heidari et al., 2015; Nawaz et al., 2019). In the current study, we stated that PHT genes could be more induced by ABA and MeJA hormones. ABA and MeJA are two important hormones that their role is known as stress-related hormones. Besides, the promoter region of $P H T$ genes contains acting-regulatory elements related to the responsiveness of low-temperature, drought and wound stress, indicating that $P H T$ genes have a high potential to regulate the cellular processes associated with increasing Camelina resistance.

\section{Conclusion}

We identified and characterized 66 PHT genes in C. sativa. Our findings revealed that $P H T$ genes in C. sativa are diverse in functions and physicochemical properties. However, the physicochemical properties, post-translational modification, and gene expression showed that the $\mathrm{PHOI}$ genes and their homolog are more involved in different cell pathways than other types of PHT families. Our results may be useful for an understanding of the PHTsmediated signaling pathways that play critical roles to increase the tolerance of plants under adverse conditions.

\section{References}

Ahmadizadeh, M., Chen, J.-T., Hasanzadeh, S., Ahmar, S., Heidari, P., 2020a. Insights into the genes involved in the ethylene biosynthesis pathway in Arabidopsis thaliana and Oryza sativa. J. Genet. Eng. Biotechnol. $18,1-20$.

Ahmadizadeh, M., Heidari, P., 2014. Bioinformatics study of transcription factors involved in cold stress. Biharean Biol. 8.

Ahmadizadeh, M., Rezaee, S., Heidari, P., 2020b. Genome-wide characterization and expression analysis of fatty acid desaturase gene family in Camelina sativa. Gene Reports 21, 100894.

Blom, N., Sicheritz- Pontén, T., Gupta, R., Gammeltoft, S., Brunak, S., 2004. Prediction of post- translational glycosylation and phosphorylation of proteins from the amino acid sequence. Proteomics 4, 1633-1649.

Bolser, D.M., Staines, D.M., Perry, E., Kersey, P.J., 2017. Ensembl plants: integrating tools for visualizing, 
bioRxiv preprint doi: https://doi.org/10.1101/2021.02 28.433256. this version posted March 1, 2021. The copyright holder for this preprint (which was not certified by peer review) is the author/funder, who has granted bioRxiv a license to display the preprint in perpetuity. It is made available under aCC-BY-NC-ND 4.0 International license.

mining, and analyzing plant genomic data, in: Plant Genomics Databases. Springer, pp. 1-31.

Brock, J.R., Dönmez, A.A., Beilstein, M.A., Olsen, K.M., 2018. Phylogenetics of Camelina Crantz.(Brassicaceae) and insights on the origin of gold-of-pleasure (Camelina sativa). Mol. Phylogenet. Evol. 127, 834-842.

Chen, A., Chen, X., Wang, H., Liao, D., Gu, M., Qu, H., Sun, S., Xu, G., 2014. Genome-wide investigation and expression analysis suggest diverse roles and genetic redundancy of Pht1 family genes in response to $\mathrm{Pi}$ deficiency in tomato. BMC Plant Biol. 14, 1-15.

Chen, C., Chen, H., Zhang, Y., Thomas, H.R., Frank, M.H., He, Y., Xia, R., 2020. TBtools-an integrative toolkit developed for interactive analyses of big biological data. bioRxiv 289660.

Cubero, B., Nakagawa, Y., Jiang, X.-Y., Miura, K.-J., Li, F., Raghothama, K.G., Bressan, R.A., Hasegawa, P.M., Pardo, J.M., 2009. The phosphate transporter PHT4; 6 is a determinant of salt tolerance that is localized to the Golgi apparatus of Arabidopsis. Mol. Plant 2, 535-552.

Daram, P., Brunner, S., Rausch, C., Steiner, C., Amrhein, N., Bucher, M., 1999. Pht2; 1 encodes a low-affinity phosphate transporter from Arabidopsis. Plant Cell 11, 2153-2166.

Faraji, S., Filiz, E., Kazemitabar, S.K., Vannozzi, A., Palumbo, F., Barcaccia, G., Heidari, P., 2020. The AP2/ERF Gene Family in Triticum durum: Genome-Wide Identification and Expression Analysis under Drought and Salinity Stresses. Genes (Basel). 11, 1464.

Finn, R.D., Mistry, J., Tate, J., Coggill, P., Heger, A., Pollington, J.E., Gavin, O.L., Gunasekaran, P., Ceric, G., Forslund, K., 2010. The Pfam protein families database. Nucleic Acids Res. 38, D211-D222.

Gasteiger, E., Hoogland, C., Gattiker, A., Duvaud, S., Wilkins, M.R., Appel, R.D., Bairoch, A., 2005. Protein identification and analysis tools on the ExPASy server, in: The Proteomics Protocols Handbook. Humana Press, Totowa, NJ, pp. 571-607. https://doi.org/10.1385/1-59259-890-0:571

Gho, Y.-S., Jung, K.-H., 2019. Comparative expression analyses of rice and Arabidopsis phosphate transporter families revealed their conserved roles for the phosphate starvation response. Plant Breed. Biotechnol. 7, $42-49$.

Gu, M., Chen, A., Sun, S., Xu, G., 2016. Complex regulation of plant phosphate transporters and the gap between molecular mechanisms and practical application: what is missing? Mol. Plant 9, 396-416. 
bioRxiv preprint doi: https://doi org/10.1101/2021.02 28.433256: this version posted March 1 2021. The copyright holder for this preprint (which was not certified by peer review) is the author/funder, who has granted bioRxiv a license to display the preprint in perpetuity. It is made available under aCC-BY-NC-ND 4.0 International license.

Guo, B., Jin, Y., Wussler, C., Blancaflor, E.B., Motes, C.M., Versaw, W.K., 2008. Functional analysis of the Arabidopsis PHT4 family of intracellular phosphate transporters. New Phytol. 177, 889-898.

Gupta, R., Brunak, S., 2002. Prediction of glycosylation across the human proteome and the correlation to protein function - PubMed. Pacific Symp. Biocomput. 310-322.

Hamburger, D., Rezzonico, E., Petétot, J.M.-C., Somerville, C., Poirier, Y., 2002. Identification and characterization of the Arabidopsis PHO1 gene involved in phosphate loading to the xylem. Plant Cell 14, 889-902.

Hassler, S., Lemke, L., Jung, B., Möhlmann, T., Krüger, F., Schumacher, K., Espen, L., Martinoia, E., Neuhaus, H.E., 2012. Lack of the Golgi phosphate transporter PHT4; 6 causes strong developmental defects, constitutively activated disease resistance mechanisms and altered intracellular phosphate compartmentation in Arabidopsis. Plant J. 72, 732-744.

Heidari, P., Ahmadizadeh, M., Izanlo, F., Nussbaumer, T., 2019. In silico study of the CESA and CSL gene family in Arabidopsis thaliana and Oryza sativa: Focus on post-translation modifications. Plant Gene 19, 100189. https://doi.org/10.1016/j.plgene.2019.100189

Heidari, P., Ahmadizadeh, M., Najafi-Zarrini, H., 2015. In Silico Analysis of Cis-Regulatory Elements on CoExpressed Genes. J. Biol. Environ. Sci 9, 1-9.

Heidari, P., Mazloomi, F., Nussbaumer, T., Barcaccia, G., 2020a. Insights into the SAM synthetase gene family and its roles in tomato seedlings under abiotic stresses and hormone treatments. Plants 9. https://doi.org/10.3390/plants9050586

Heidari, P., Mazloomi, F., Sanaeizade, S., 2020b. Optimization Study of Nickel and Copper Bioremediation by Microbacterium oxydans Strain CM3 and CM7. Soil Sediment Contam. An Int. J. 29, 438-451. https://doi.org/10.1080/15320383.2020.1738335

Heidari, P., Panico, A., 2020. Sorption Mechanism and Optimization Study for the Bioremediation of Pb(II) and Cd(II) Contamination by Two Novel Isolated Strains Q3 and Q5 of Bacillus sp. Int. J. Environ. Res. Public Health 17, 4059. https://doi.org/10.3390/ijerph17114059

Huang, S., Xin, S., Xie, G., Han, J., Liu, Z., Wang, B., Zhang, S., Wu, Q., Cheng, X., 2020. Mutagenesis reveals that the rice OsMPT3 gene is an important osmotic regulatory factor. Crop J. 8, 465-479. 
bioRxiv preprint doi: https://doi org/10.1101/2021.02 28.433256. this version posted March 1, 2021. The copyright holder for this preprint (which was not certified by peer review) is the author/funder, who has granted bioRxiv a license to display the preprint in perpetuity. It is made available under aCC-BY-NC-ND 4.0 International license.

Jia, H., Ren, H., Gu, M., Zhao, J., Sun, S., Zhang, X., Chen, J., Wu, P., Xu, G., 2011. The phosphate transporter gene OsPht1; 8 is involved in phosphate homeostasis in rice. Plant Physiol. 156, 1164-1175.

Karthikeyan, A.S., Varadarajan, D.K., Mukatira, U.T., D’Urzo, M.P., Damsz, B., Raghothama, K.G., 2002. Regulated expression of Arabidopsis phosphate transporters. Plant Physiol. 130, 221-233.

Kumar, S., Stecher, G., Li, M., Knyaz, C., Tamura, K., 2018. MEGA X: molecular evolutionary genetics analysis across computing platforms. Mol. Biol. Evol. 35, 1547-1549.

Lee, H.S., Qi, Y., Im, W., 2015. Effects of N-glycosylation on protein conformation and dynamics: Protein Data Bank analysis and molecular dynamics simulation study. Sci. Rep. 5, 1-7. https://doi.org/10.1038/srep08926

Lee, H.Y., Yoon, G.M., 2018. Regulation of ethylene biosynthesis by phytohormones in etiolated rice (Oryza sativa L.) seedlings. Mol. Cells 41, 311-319. https://doi.org/10.14348/molcells.2018.2224

Lescot, M., Déhais, P., Thijs, G., Marchal, K., Moreau, Y., Van de Peer, Y., Rouzé, P., Rombauts, S., 2002. PlantCARE, a database of plant cis-acting regulatory elements and a portal to tools for in silico analysis of promoter sequences. Nucleic Acids Res. 30, 325-327.

Letunic, I., Bork, P., 2019. Interactive Tree of Life (iTOL) v4: Recent updates and new developments. Nucleic Acids Res. 47, W256-W259. https://doi.org/10.1093/nar/gkz239

Liu, B., Zhao, S., Wu, X., Wang, X., Nan, Y., Wang, D., Chen, Q., 2017. Identification and characterization of phosphate transporter genes in potato. J. Biotechnol. 264, 17-28.

Liu, F., Chang, X.-J., Ye, Y., Xie, W.-B., Wu, P., Lian, X.-M., 2011. Comprehensive sequence and whole-lifecycle expression profile analysis of the phosphate transporter gene family in rice. Mol. Plant 4, 11051122.

Liu, T.-Y., Huang, T.-K., Tseng, C.-Y., Lai, Y.-S., Lin, S.-I., Lin, W.-Y., Chen, J.-W., Chiou, T.-J., 2012. PHO2-dependent degradation of PHO1 modulates phosphate homeostasis in Arabidopsis. Plant Cell 24, $2168-2183$.

Liu, T.-Y., Huang, T.-K., Yang, S.-Y., Hong, Y.-T., Huang, S.-M., Wang, F.-N., Chiang, S.-F., Tsai, S.-Y., Lu, W.-C., Chiou, T.-J., 2016. Identification of plant vacuolar transporters mediating phosphate storage. Nat. Commun. 7, 1-11. 
bioRxiv preprint doi: https://doi org/10.1101/2021.02 28.433256 this version posted March 1 2021. The copyright holder for this preprint (which was not certified by peer review) is the author/funder, who has granted bioRxiv a license to display the preprint in perpetuity. It is made available under aCC-BY-NC-ND 4.0 International license.

Marchler-Bauer, A., Derbyshire, M.K., Gonzales, N.R., Lu, S., Chitsaz, F., Geer, L.Y., Geer, R.C., He, J., Gwadz, M., Hurwitz, D.I., 2015. CDD: NCBI’s conserved domain database. Nucleic Acids Res. 43, D222-D226.

Miyaji, T., Kuromori, T., Takeuchi, Y., Yamaji, N., Yokosho, K., Shimazawa, A., Sugimoto, E., Omote, H., Ma, J.F., Shinozaki, K., 2015. AtPHT4; 4 is a chloroplast-localized ascorbate transporter in Arabidopsis. Nat. Commun. 6, 1-11.

Młodzińska, E., Zboińska, M., 2016. Phosphate uptake and allocation-a closer look at Arabidopsis thaliana L. and Oryza sativa L. Front. Plant Sci. 7, 1198.

Muchhal, U.S., Pardo, J.M., Raghothama, K.G., 1996. Phosphate transporters from the higher plant Arabidopsis thaliana. Proc. Natl. Acad. Sci. 93, 10519-10523.

Murphy, E.J., 2016. Camelina (Camelina sativa), in: Industrial Oil Crops. Elsevier, pp. 207-230.

Nawaz, Z., Kakar, K.U., Ullah, R., Yu, S., Zhang, J., Shu, Q.Y., Ren, X. liang, 2019. Genome-wide identification, evolution and expression analysis of cyclic nucleotide-gated channels in tobacco (Nicotiana tabacum L.). Genomics 111, 142-158. https://doi.org/10.1016/j.ygeno.2018.01.010

Nussaume, L., Kanno, S., Javot, H., Marin, E., Nakanishi, T.M., Thibaud, M.-C., 2011. Phosphate import in plants: focus on the PHT1 transporters. Front. Plant Sci. 2, 83.

Poirier, Y., Bucher, M., 2002. Phosphate transport and homeostasis in Arabidopsis. Arab. book/American Soc. Plant Biol. 1.

Raghothama, K.G., 2000. Phosphate transport and signaling. Curr. Opin. Plant Biol. 3, 182-187.

Remy, E., Cabrito, T.R., Batista, R.A., Teixeira, M.C., Sá-Correia, I., Duque, P., 2012. The Pht1; 9 and Pht1; 8 transporters mediate inorganic phosphate acquisition by the Arabidopsis thaliana root during phosphorus starvation. New Phytol. 195, 356-371.

Rezaee, S., Ahmadizadeh, M., Heidari, P., 2020. Genome-wide characterization, expression profiling, and posttranscriptional study of GASA gene family. Gene Reports 20, 100795. https://doi.org/10.1016/j.genrep.2020.100795

Ruili, L., Jiaoling, W., Lei, X., Meihao, S., Keke, Y., Hongyu, Z., 2020. Functional Analysis of Phosphate Transporter OsPHT4 Family Members in Rice. Rice Sci. 27, 493-503. 
bioRxiv preprint doi: https://doi org/10.1101/2021.02 28.433256. this version posted March 1 2021. The copyright holder for this preprint (which was not certified by peer review) is the author/funder, who has granted bioRxiv a license to display the preprint in perpetuity. It is made available under aCC-BY-NC-ND 4.0 International license.

Shin, Heungsop, Shin, Hwa-Soo, Dewbre, G.R., Harrison, M.J., 2004. Phosphate transport in Arabidopsis: Pht1; 1 and Pht1; 4 play a major role in phosphate acquisition from both low-and high-phosphate environments. Plant J. 39, 629-642.

Silva-Sanchez, C., Li, H., Chen, S., 2015. Recent advances and challenges in plant phosphoproteomics. Proteomics 15, 1127-1141. https://doi.org/10.1002/pmic.201400410

Smith, F.W., 2002. The phosphate uptake mechanism, in: Food Security in Nutrient-Stressed Environments: Exploiting Plants' Genetic Capabilities. Springer, pp. 235-244.

Smith, F.W., Mudge, S.R., Rae, A.L., Glassop, D., 2003. Phosphate transport in plants. Plant Soil 248, $71-83$.

Solis, A., Vidal, I., Paulino, L., Johnson, B.L., Berti, M.T., 2013. Camelina seed yield response to nitrogen, sulfur, and phosphorus fertilizer in South Central Chile. Ind. Crops Prod. 44, 132-138.

Sun, T., Li, M., Shao, Y., Yu, L., Ma, F., 2017. Comprehensive genomic identification and expression analysis of the phosphate transporter (PHT) gene family in apple. Front. Plant Sci. 8, 426.

Teng, W., Zhao, Y.-Y., Zhao, X.-Q., He, X., Ma, W.-Y., Deng, Y., Chen, X.-P., Tong, Y.-P., 2017. Genomewide identification, characterization, and expression analysis of PHT1 phosphate transporters in wheat. Front. Plant Sci. 8, 543.

Tran, H.T., Hurley, B.A., Plaxton, W.C., 2010. Feeding hungry plants: the role of purple acid phosphatases in phosphate nutrition. Plant Sci. 179, 14-27.

Versaw, W.K., Harrison, M.J., 2002. A chloroplast phosphate transporter, PHT2; 1, influences allocation of phosphate within the plant and phosphate-starvation responses. Plant Cell 14, 1751-1766.

Wang, J., Yang, Y., Liao, L., Xu, J., Liang, X., Liu, W., 2019. Genome-wide identification and functional characterization of the phosphate transporter gene family in Sorghum. Biomolecules 9, 670.

Wang, Y., Ribot, C., Rezzonico, E., Poirier, Y., 2004. Structure and expression profile of the Arabidopsis PHO1 gene family indicates a broad role in inorganic phosphate homeostasis. Plant Physiol. 135, 400-411.

Yang, J., Zhou, J., Zhou, H.-J., Wang, M.-M., Liu, M.-M., Ke, Y.-Z., Li, P.-F., Li, J.-N., Du, H., 2020. Global Survey and Expressions of the Phosphate Transporter Gene Families in Brassica napus and Their Roles in Phosphorus Response. Int. J. Mol. Sci. 21, 1752. 
bioRxiv preprint doi: https://doi.org/10.1101/2021.02.28.433256; this version posted March 1, 2021. The copyright holder for this preprint

(which was not certified by peer review) is the author/funder, who has granted bioRxiv a license to display the preprint in perpetuity. It is made available under aCC-BY-NC-ND 4.0 International license.

Yu, G., Huang, S., He, R., Li, Y., Cheng, X., 2018. Transgenic Rice Overexperessing a Tomato Mitochondrial Phosphate Transporter, SIMPT3; 1, Promotes Phosphate Uptake and Increases Grain Yield. J. Plant Biol. $61,383-400$.

Zhang, C., Meng, S., Li, M., Zhao, Z., 2016. Genomic identification and expression analysis of the phosphate transporter gene family in poplar. Front. Plant Sci. 7, 1398. 